\title{
Intranasal Delivery of Immunotherapeutic Nanoformulations for Treatment of Glioma Through in situ Activation of Immune Response [Corrigendum]
}

Yin P, Li H, Ke C, et al. Int J Nanomedicine. 2020;15:14991515.

The authors have advised Figure 5A on page 1511 is incorrect. Due to an error at the time of figure assembly day $21 \mathrm{Au} @ \mathrm{PP} /$
poly(I:C)+TMZ and day $28 \mathrm{Au} @ \mathrm{PP} /$ poly(I:C)+TMZ in the HE $200 \times$ row were duplicated. The correct Figure 5 is shown below.

A

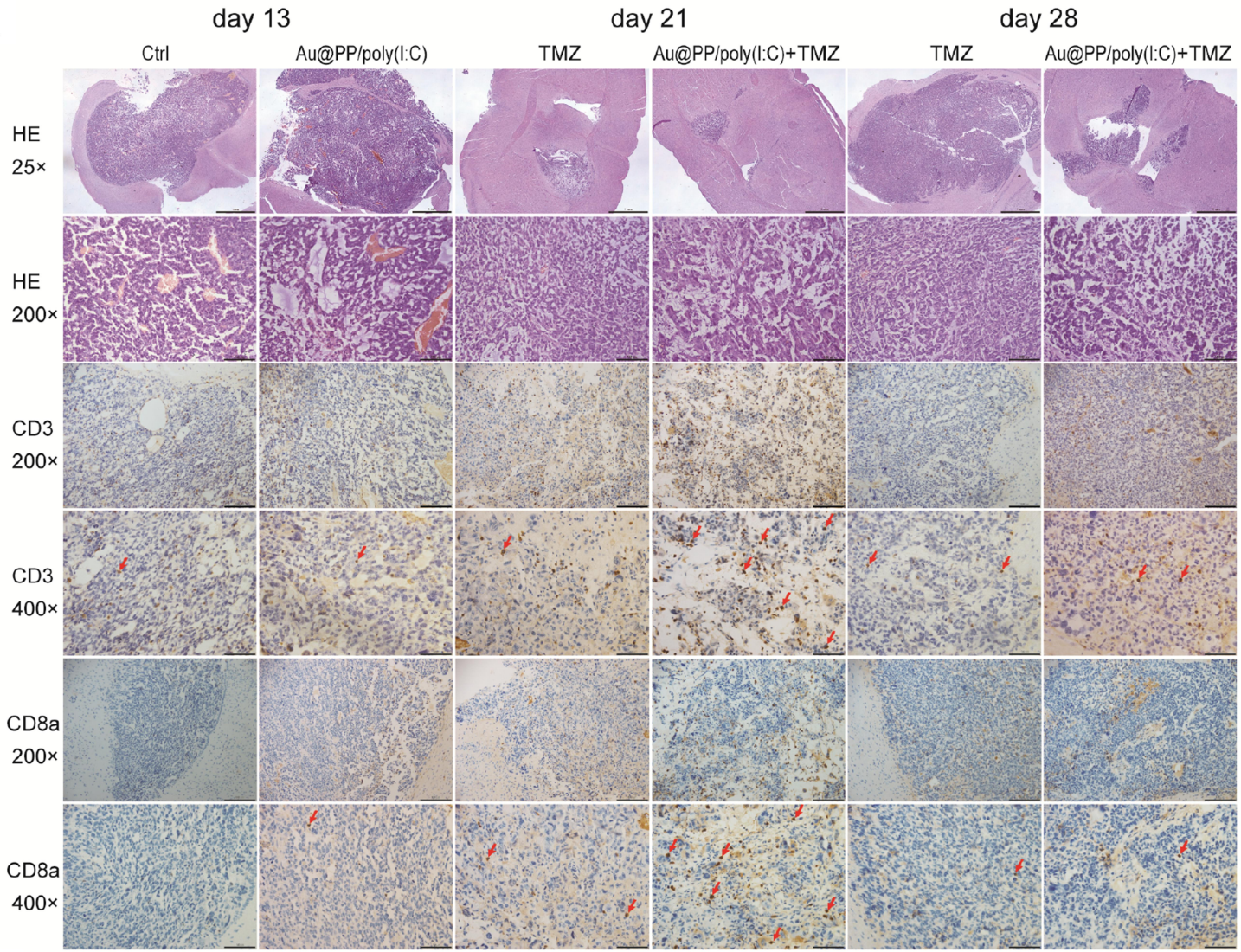

Figure 5 Continued.

International Journal of Nanomedicine 2020:15 8873-8874 
B
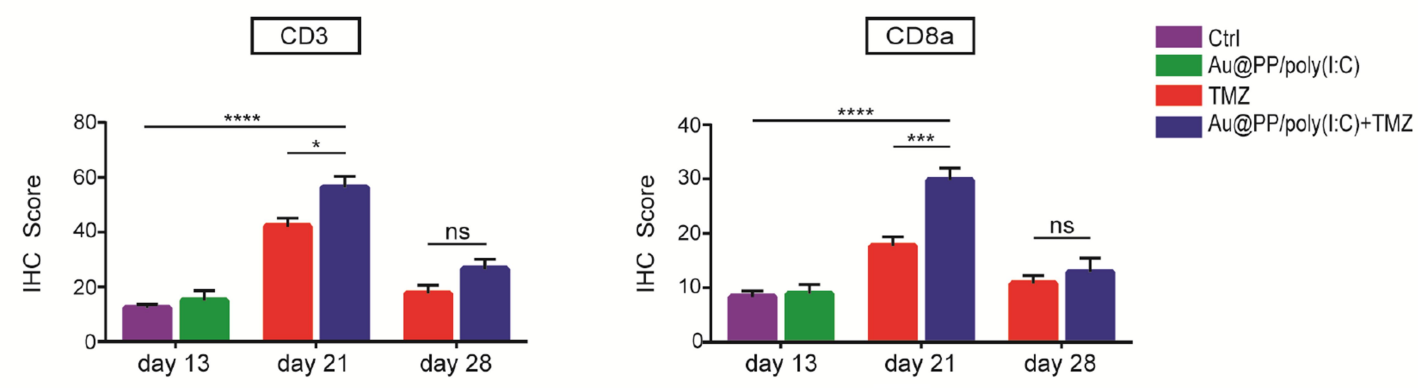

C

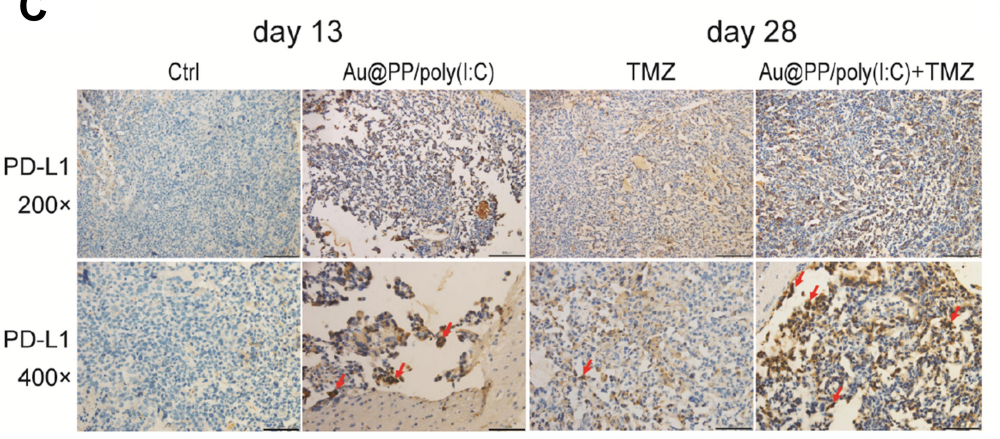

D

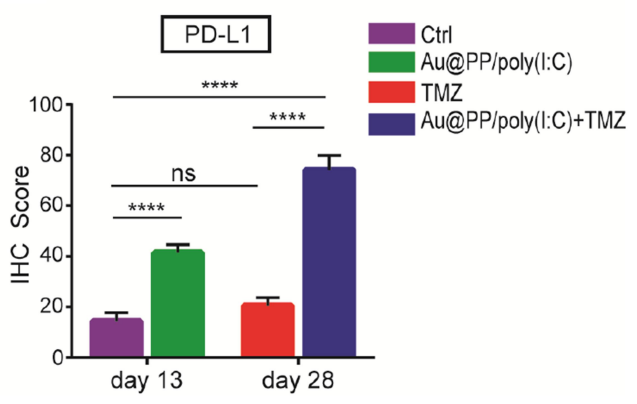

Figure 5 Intranasal Au@PP/poly(I:C) combined with TMZ improves T-cell infiltration and PD-LI expression in intracranial glioma. (A, C) Representative images of H\&E and immunohistochemical staining for CD3, CD8a and PD-LI in GL26I glioma. The tumor tissue was collected on day I3, day 21 and day 28 after cell inoculating. The images are magnified $25 \times, 200 \times$ and $400 \times$ (the scale bars within the photomicrographs are 1000, 100 and 50 microns in length). The red arrows show the positive cells. (B, D) The IHC membrane staining intensity of each cell in a fixed field is determined as $0,1+, 2+$, or $3+$, and the $\mathrm{IHC}$ score was assigned using the following formula: $[1 \times(\%$ cells $1+)+2 \times$ $(\%$ cells $2+)+3 \times(\%$ cells $3+)$ ]. We took 3 pictures with $200 \times$ magnification per cut section of the brain tumors and counterstained cells from each picture and calculated an average from the three. The results at least include 6 mice per each group. Mean \pm SEM, $n=6-9$ in each group. ns: no significant difference, $* p<0.05$, $* * * p<0.001$ and $* * * * p<0.0001$.

The authors apologize for this error and advise it does not affect the results of the paper.

\section{Publish your work in this journal}

The International Journal of Nanomedicine is an international, peerreviewed journal focusing on the application of nanotechnology in diagnostics, therapeutics, and drug delivery systems throughout the biomedical field. This journal is indexed on PubMed Central, MedLine, CAS, SciSearch ${ }^{\mathbb{2}}$, Current Contents ${ }^{\mathbb{R}} /$ Clinical Medicine, $^{2}$
Journal Citation Reports/Science Edition, EMBase, Scopus and the Elsevier Bibliographic databases. The manuscript management system is completely online and includes a very quick and fair peer-review system, which is all easy to use. Visit http://www.dovepress.com/ testimonials.php to read real quotes from published authors. 